\title{
KEOTENTIKAN AJARAN TASAWUF
}

\begin{abstract}
Abstrak
Tuduhan tentang ketidakotentikan ajaran tasawuf masih terjadi di era kontemporer ini. Tulisan ini ikut serta menjawab tuduhan ini. Melalui penelusuran pengertian dan asal usul kata sufi (tasawuf) serta sejarah munculnya tasawuf menunjukkan bahwa tuduhan itu tidak benar dikarenakan tidak dapat dibuktikan. Memang terdapat suatu bukti akan adanya pengaruh dari luar, tetapi disebabkan pengaruh itu terjadi ketika tasawuf telah terpancang kuat, tidak terjadi ketika tasawuf masih dalam bentuk gerakan zuhud, maka pengaruh itu hanya menyentuh di permukaan, tidak menyentuh esensi ajaran tasawuf. Dengan demikian, tasawuf itu otentik ajaran Islam, otentik bersumber dari al-Qur'an dan al-Hadis, bukan sesuatu yang diselundupkan ke dalam Islam.
\end{abstract}

\section{Kata KunCi:}

Tasawuf, Zuhud (Asketik), Bid'ah, Otentik, Spiritualitas

\section{Abstract}

The accusation against the authenticity of tasawuf (Islamic mysticism or Sufism) teachings still lingers on in this contemporary era. This article contributes on answering this accusation by revisiting the nature and the origin of tasawuf. By examining the history of tasawuf, this article argues that the accusation is not true and cannot be proven. Though there is some evidence that external influence occurs, this only touches the surface (in the form of zuhud movement) not in the essence of the Sufism teaching. Therefore it can be concluded that Sufism is authentically Islamic teaching originally from Quran and hadiths, thus it is not transferred to Islam.

\section{KeY WoRDS:}

Sufism, Ascetic, Heresy, Authentic, Spirituality

*) Dosen "Ilmu Pemikiran Islam" Fakultas Ilmu Tarbiyah dan Keguruan (FITK) UIN Syarif Hidayatullah Jakarta. Jl. Ir. H. Juanda No. 95 Ciputat 15413. Email: dimyati@uinjkt.ac.id atau dimyatisajari@yahoo.com

** Naskah diterima September 2015, direvisi Oktober 2015, disetujui untuk dimuat November 2015. 


\section{A. Pendahuluan}

Dewasa ini, tuduhan tentang ketidakotentikan tasawuf masih terjadi. Misalnya, Ahmad bin Abdul Aziz al-Hushain dan Abdullah Mustofa Numsuk menyatakan bahwa tasawuf itu merupakan ajaran Buddha. ${ }^{1}$ Muhammad alAbduh dan Thariq Abdul Halim mengatakan bahwa tasawuf merupakan bid'ah dalam Islam dan kaum sufi dipandang sebagai ahli bid'ah. ${ }^{2}$ Di Indonesia, Hartono Ahmad Jaiz, melalui penukilannya terhadap fatwa-fatwa Saudi Arabia, menyetujui bahwa tasawuf/tarekat itu tidak ada dasarnya di dalam Al-Qur'an dan Al-Sunnah, sehingga tasawuf/tarekat dia vonis sebagai bid'ah yang sesat menyesatkan. Dzikir bersama-sama pun dikelompokkan Jaiz termasuk kategori bid'ah. $^{3}$

Tuduhan itu, seperti tuduhan bahwa kaum sufi menolak ibadah formal (aspek ritual Islam); kaum sufi hanya mengurusi penyucian batin; kaum sufi menyimpang dari syari'at dan mengabaikan hukum-hukum syari'at yang lahiriah; ${ }^{4}$ merupakan rangkaian panjang yang senantiasa mewarnai sejarah tasawuf, dari dulu hingga sekarang. ${ }^{5}$ Tuduhan ini, sebenarnya, telah ditanggapi oleh kaum sufi atau para pendukung tasawuf. Akan tetapi, karena yang mereka kehendaki adalah para pelaku tasawuf itu meninggalkan dunia tasawuf, bukan jawaban atau penjelasan, maka sebagian mereka

\footnotetext{
${ }^{1}$ Ahmad bin Abdul Aziz al-Hushain dan Abdullah Mustofa Numsuk, Kesesatan Sufi: Tasawuf, Ajaran Budha! (Jakarta: Pustaka as-Sunnah, 2001), 6-8.

${ }^{2}$ Muhammad al-Abduh dan Thariq Abdul Halim, Koreksi bagi Kaum Sufi, terj. A. Bahauddin dan Muslim Muslih (Jakarta: Kalam Mulia, 1998), 1-5. Bid'ah adalah mengada-ada dalam Islam, yakni suatu amaliah yang belum pernah dicontohkan sebelumnya oleh Nabi Saw.

${ }^{3}$ Hartono Ahmad Jaiz, Aliran dan Paham Sesat di Indonesia (Jakarta: Pustaka Al-Kautsar, 2002), 256-59.

${ }^{4}$ Adanya tuduhan-tuduhan ini diungkap Julian Johansen, Sufism and Islamic Reform in Egypt: The Battle for Islamic Tradition (Oxford: Clarendon Press, 1996), 1 dan Syekh Fadhlalla Haeri, The Elements of Sufism (Shaftesbury, Dorset, Brisbane dll: Element, 1997), $77-8$.

${ }^{5}$ Atas dasar inilah, barangkali, yang melatari Johansen berpendapat bahwa tasawuf merupakan satu-satunya "khazanah spiritual dan intelektual" dalam Islam yang paling menyita perhatian hampir di sepanjang sejarah Islam. Menurut Johansen, tasawuf senantiasa menjadi sebuah isu perdebatan. Julian Johansen, Sufism and Islamic Reform in Egypt,1. Lihat pula Fazlur Rahman, Islam (Chicago dan London: University of Chicago Press, 1979), 134 dan Elizabeth Sirriyeh, Sufis and Anti-Sufis: The Defence, Rethinking and Rejection of Sufism in the Modern World (RoutledgeCurzon: Taylor \& Francis Group, 1999).
}

bersikukuh tidak mau menerima jawaban itu. Akibatnya, mereka (sebagian kaum eksoterik itu) tetap melakukan "penyerangan" terhadap tasawuf hingga sekarang. Tentu saja tidak semua pengkritik tasawuf itu selamanya anti-tasawuf. Justeru sebagian dari ulama terkemuka, sebagaimana dikemukakan Fazlur Rahman, akhirnya bergabung dan menjadi pendukung utama kehidupan sufistik. ${ }^{6}$

Terlepas dari ketidaksediaan sebagian para penuduh tasawuf itu hingga kini (dan tidak menutup kemungkinan mereka pun dapat berubah), makalah ini bermaksud untuk ikut serta memberikan jawaban itu. Tulisan ini disajikan untuk melengkapi tulisan penulis tentang "Loyalitas Kaum Sufi terhadap Syari'at" yang telah dipublikasikan di Jurnal Ahkam. ${ }^{7}$ Bila di tulisan "Loyalitas Kaum Sufi terhadap Syari'at" bertujuan untuk memberikan jawaban bahwa hukum syari'at merupakan supremasi tertinggi dalam Islam, sehingga tidak seorang pun umat, apalagi kaum sufi, yang menolak atau mengabaikan syari'at, maka tulisan ini hendak menunjukkan bahwa tasawuf itu otentik Islam, otentik berdasarkan al-Qur'an dan al-Hadis, dan bukan sesuatu di luar Islam yang diselundupkan ke dalam Islam. Tulisan ini sejalan dengan jawaban Abû Bakr Sirâj al-Dîn terhadap tuduhan kaum ulama yang menuduh bahwa praktekpraktek dan teori-teori sufisme tidak berasal dari era kerasulan. Dalam artikelnya "The Nature and Origin of Sufism" Sirâj al-Dîn menyatakan bahwa hakikat dan asal-usul praktek-praktek dan teoriteori sufisme benar-benar berasal dari era kerasulan, bersumber dari al-Qur'an dan alSunnah. ${ }^{8} \mathrm{Hal}$ yang sama diungkap oleh penulispenulis yang bukunya dirujuk dalam makalah ini, semisal A.J. Arberry, Titus Burckhardt, Reynold A. Nicholson, dan MartinLings, yang menjawab tuduhan itu dan menunjukkan keotentikan ajaran tasawuf.

Makalah ini, seperti diungkap di atas, bertujuan ikut serta memberikan jawaban terhadap tuduhan mengenai ketidakotentikan

\footnotetext{
${ }^{6}$ Fazlur Rahman, Islam, 134-37.

${ }^{7}$ Fakultas Syariah dan Hukum UIN Syarif Hidayatullah Jakarta, Ahkam: Jurnal Ilmu Syariah, Vol. XIV No. 1, Januari 2014, 12334.

${ }^{8}$ Abû Bakr Sirâj al-Dîn, "The Nature and Origin of Sufism," dalam Seyyed Hossein Nasr (Ed.), Islamic Spirituality (New York: Crossroad, 1987), 236.
} 
ajaran tasawuf. Benarkah demikian? Benarkah tasawuf tidak otentik ajaran Islam? Dalam rangka menjawab pertanyaan ini, penyajian makalah ini dibagi menjadi dua bagian, yaitu bagian tentang pengertian dan asal usul kata tasawuf serta bagian tentang sejarah tasawuf. Asumsi yang dibangun dalam tulisan ini adalah: tidak mungkin tasawuf sebagai suatu ajaran yang diamalkan umat Islam dan pengamalan itu tetap eksis berabad-abad hingga sekarang kalau tidak otentik Islam, apalagi bertentangan dengan Islam. Suatu ajaran yang tidak bersumber dari Islam dan bertentangan dengan Islam, pastilah dia akan cepat sirna dari dunia Islam. Kenyataannya, tasawuf tetap eksis hingga kini dan pendukung atau pelaku tasawuf tidak pernah surut sampai dewasa ini. Hal ini dapat diasumsikan, tasawuf itu otentik ajaran Islam.

\section{B. Pengertian Tasawuf dan Asal-usul Kata Tasawuf}

Sebelum mengkaji tentang pengertian tasawuf dan asal-usul kata tasawuf, tepatlah

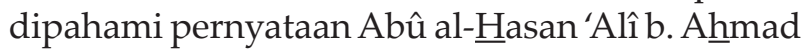
bin Sahl al-Bûsyinjî (w. $348 \mathrm{H}$ ), sebagaimana dinukil 'Alî ibn 'Utsmân al-Hujwîrî (w. 463 H/ $1071 \mathrm{M}$ ). Pernyataan al-Bûsyinjî ini penting diketahui bagi orang yang mempersoalkan istilah tasawuf atau orang yang memandang istilah tasawuf sebagai istilah yang baru, yang konsekuensinya-sebagai istilah baru-tasawuf dianggap tidak berasal dari Islam. Padahal, sebagai sebuah ajaran, tasawuf itu telah diamalkan sebelum istilah tasawuf itu ada atau sebelum istilah tasawuf itu menjadi populer di tengah-tengah umat. Hal inilah yang dapat dipahami dari ungkapan al-Bûsyinjî yang menyatakan bahwa tasawuf pada masanya merupakan nama tanpa hakikat, tetapi sebelum eranya(tasawuf itu) merupakan hakikat tanpa nama. ${ }^{9}$

Ungkapan al-Bûsyinjî itu mengisyaratkan bahwa pada masanya istilah kata tasawuf itu sudah menjadi suatu istilah yang sangat populer di masyarakat, tetapi hakikat pengamalan tasawuf itu sendiri diakuinya tiada lagi. Namun, pada era sebelumnya al-Bûsyinjî mengakui bahwa

\footnotetext{
9 'Alî ibn 'Utsmân al-Hujwîrî, Kasyf al-Mahjûub, terj. ke dalam Bahasa Arab Is'ad Abd al-Hâdî Qundail (Kairo: Dar al-Kutub, 1974), 239.
}

pengamalan tasawuf justru merupakan realita yang hakiki yang tidak dapat dipungkiri lagi. Meski pandangan al-Bûsyinjî ini sangat bermakna, tetapi pandangan al-Bûsyinjî ini belum tentu disetujui oleh semua pendukung sufi yang sama-sama bermaksud membela tasawuf dan kaum sufi, seperti yang akan terlihat dalam tulisan ini. Adapun penilaiannya bahwa pada masa alBûsyinjî tasawuf itu nama tanpa hakikat, boleh dikata pula sebagai suatu generalisasi yang bersifat pukul rata. Oleh karena itu, penjelasan mengenai pengertian dan asal usul kata tasawuf akan diketahui adanya perbedaan pandangan di antara pendukung tasawuf ini, meski keduanya sama-sama melakukan pembelaan terhadap tasawuf dan kaum sufi dari segala bentuk tuduhan.

Tentang pengertian tasawuf terdapat banyak sekali pengertian atau definisi. Ibrâhîm Basyûnî mengatakan bahwa hingga abad ke-3 H saja, yakni sejak tahun $200 \mathrm{H}$ sampai tahun $334 \mathrm{H}$ (tahun wafatnya al-Syibli), telah terdapat empat puluh definisi. Menurut Basyûnî, banyaknya definisi tentang tasawuf ini dikarenakan sulitnya menghasilkan definisi yang mencakup keseluruhan makna mengenai tasawuf. Basyûnî mengatakan bahwa hal ini disebabkan kaum sufi tidak membatasi tasawuf itu sebagai ilmu sebagaimana para filosof membatasi filsafat. ${ }^{10}$ Hampir senada dengan pendapat Basyûnî ini, Reynold A. Nicholson mengatakan bahwa adanya beberapa definisi tentang tasawuf justru menunjukkan makna yang sangat penting yang terletak pada kenyataan bahwa tasawuf itu sesungguhnya merupakan sesuatu yang tidak dapat didefinisikan. ${ }^{11}$ Lebih lanjut Nicholson mengemukakan bahwa beragam pengertian tentang tasawuf itu hanya mampu menjelaskan apa yang telah dialami sang sufi itu sendiri. Oleh karena itu, menurut Nicholson, tidak akan pernah ada rumusan yang utuh yang mampu menyentuh setiap relung pengalaman spiritual manusia; rumusan yang ada hanya mampu menyentuh sebagian saja dari beberapa segi dan sifat tasawuf.

Seorang sufi yang hidup di abad ke-4 H,

${ }^{10}$ Ibrâhîm Basyûnî, Nasy'at al-Tashawwuf al-Islâmî (Kairo: Dâr al-Ma'ârif Bimishra, t.t.), 17.

${ }^{11}$ Reynold A. Nicholson, Th Mystics of Islam (London: Routledge \& Kegan Paul Ltd., 1966), 25. 
yaitu Abû Nashr al-Sarrâj al-Thûsî (w. 377/988) di dalam kitabnya Al-Luma' mengutip tujuh definisi mengenai tasawuf. ${ }^{12}$ Definisi pertama diambil dari Muhammad bin 'Alî al-Qashshâb, guru al-Junaid al-Baghdâdî (w. 298 H/911 M). Menurut al-Qashshâb, seperti dinukil al-Sarrâj, tasawuf adalah akhlak yang mulia, yang tampak jelas di zaman yang mulia, yang berasal dari orang yang mulia, beserta kaum yang mulia. Adapun menurut al-Junaid, tokoh kedua yang pendapatnya dikutip al-Sarrâj, tasawuf adalah hendaknya engkau bersama Allah tanpa menyertakan yang selain-Nya.

Kemudian, sufi yang ketiga yang dirujuk alSarrâj adalah Ruwaim bin Alhmad (w. 303/915). Dalam pandangan Ruwaim, tasawuf adalah mengarahkan diri bersama Allah atas apa yang dikehendaki-Nya. Tokoh yang keempat yang dinukil al-Sarrâj adalah Sumnûn bin ㅂamzat. Sufi ini menyatakan bahwa tasawuf adalah hendaknya engkau merasa tidak memiliki sesuatu dan tidak dimilik oleh sesuatu. Selanjutnya, Abû Muhammad al-Jarîrî (w. w. 311 H). Bagi al-Jarîrî, tasawuf adalah masuk ke dalam setiap akhlak yang mulia dan keluar dari setiap akhlak yang hina. Sementara 'Amr bin'Utsmân al-Makkî berpendapat bahwa tasawuf adalah hendaknya seorang hamba melakukan sesuatu yang utama di setiap waktu itu. Terakhir, tokoh yang dirujuk adalah 'Alî bin 'Abd al-Rahmân al-Qannâd. Menurutnya, sebagaimana ditulis al-Sarrâj, tasawuf adalah menempuh maqam-maqam dan mempertahankannya dengan melanggengkan berkomunikasi dengan Allah. ${ }^{13}$

Selain ketujuh pengertian di atas, al-Sarrâj masih menukil beberapa definisi tentang tasawuf ketika membahas mengenai jati diri kaum sufi. Al-Sarrâj mengatakan bahwa banyak jawaban tentang tasawuf yang diberikan oleh tokohtokoh yang kesufiannya tidak diragukan lagi. Di antara jamaah yang memberikan jawaban ini, menurut al-Sarrâj, adalah Ibrâhîm b. al-Muwallad al-Raqqî. Al-Sarrâj menginformasikan bahwa alRaqqî ini memberikan jawaban tentang tasawuf lebih dari seratus jawaban. Kemudian, al-Sarrâj mengelompokkan jawaban-jawaban syaikh sufi

${ }^{12}$ Abû Nashr al-Sarrâj al-Thûsî, al-Luma', Pentahqiq dan

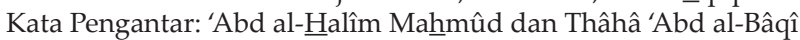
Surûr (Kairo: Maktabat al-Tsaqâfat al-Dîniyyat, t.t.), 45.

${ }^{13} \mathrm{Abû}$ Nashr al-Sarrâj, Al-Luma', 45. mengenai tasawuf itu menjadi tiga kelompok. Pertama, jawaban yang membutuhkan persyaratan ilmu, yaitu menyucikan hati dari kotoran-kotoran, berakhlak mulia ketika bersama dengan sesama, dan mengikuti Rasulullah Saw. dalam syariah. Kedua, jawaban yang mempergunakan bahasa hakikat (lisân al-haqî̀at), yaitu tiadanya rasa memiliki, keluar dari perbudakan sifat hina, dan mencukupkan diri hanya dengan Sang Pencipta langit. Ketiga, jawaban melalui bahasa Tuhan (lisân al- $\underline{H} a q q)$, yakni menyucikan kekotoran mereka melalui kesucian-Nya dan menyucikan sifat-sifat hina mereka melalui Sifat-Nya. ${ }^{14}$

Di samping itu, Abû Bakr Muhammad alKalâbâdzî (w. 385 H/995 M), seorang sufi yang hidup sezaman dengan al-Sarrâj, mengutip pandangan Abû al-Hasan al-Nûrî (w. 295/908) dan al-Junaid al-Baghdâdî. ${ }^{15}$ Tokoh kedua yang dikutip al-Kalâbâdzî ini, yakni al-Junaid, pandangannya telah dinukil al-Sarrâj di atas, tetapi pandangan al-Junaid tentang tasawuf berbeda antara yang dinukil al-Kalâbâdzî dengan yang dirujuk al-Sarrâj tersebut. Menurut alNûrî, seperti dikutip al-Kalâbâdzî, tasawuf adalah meninggalkan setiap kesenangan hawa nafsu, ${ }^{16}$ sedangkan dalam pandangan al-Junaid, sebagaimana dinukil al-Kalâbâdzî, tasawuf adalah sucinya hati dari hal-hal yang bertalian dengan makhluk, memutuskan watak-watak bawaan instinktif (yang rendah), memadamkan sifat-sifat kebiologisan (yang buruk), menjauhi ajakan hawa nafsu, menempatkan sifat-sifat spiritual (sifat yang baik), mengkaji ilmu-ilmu hakikat, mengamalkan sesuatu yang keutamaannya lebih abadi, memberikan nasihat untuk seluruh umat, benar-benar patuh kepada Allah, dan mengikuti Rasulullah Saw. di dalam melaksanakan syari'at.

Dari pengertian-pengertian itu dapat dilihat adanya benang merah yang menghubungkannya, yaitu akhlak. Dari sinilah, barangkali, yang menyebabkan beberapa sufi, semisal Abû al-Hasan al-Nûrî, Abû Muhammad Murta'isy (w. 328/939) dan Abû 'Alî al-Qarmînî,

\footnotetext{
${ }^{14}$ Abû Nashr al-Sarrâj, Al-Luma', 48.

${ }^{15}$ Abû Bakr Muhammad al-Kalâbâdzî, Al-Ta'arruf li Madzhab Ahl al-Tashawwuf, selanjutnya ditulis Al-Ta'arruf (Kairo: Maktabat al-Kulliyyât al-Azhariyyat, 1969), 34.

16 Definisi al-Nûrî ini dinukil pula ole 'Alî ibn 'Utsmân alHujwîrî di dalam kitabnya Kasyf al-Mahjûu, 232.
} 
yang pendapatnya dinukil al-Hujwîrî mengaitkan tasawuf dengan akhlak. ${ }^{17}$ Abû alHasan al-Nûrî, misalnya, mengatakan bahwa tasawuf itu bukan bentuk dan bukan pula ilmu pengetahuan, tetapi akhlak. Begitu pula Abû Muhammad Murta'isy mendefinisikan tasawuf sebagai akhlak yang baik (al-tashawwuf husn alkhuluq). Dengan nada yang hampir sama, Abû 'Alî al-Qarmînî menyatakan bahwa tasawuf adalah akhlak kerelaan (al-akhlâq al-mardhiyyaț). "Oleh karena itu," tulis al-Hujwîrî, "para pendukung keyakinan ini telah menyucikan akhlak dan tindakan mereka serta berusaha membebaskan diri mereka dari noda-noda bawaan." Dikarenakan kesucian akhlak, tindakan dan kesucian batin (jiwa) mereka itulah mereka disebut sufi." 18

Untuk memahami lebih jelas lagi mengenai makna atau pengertian tasawuf di atas, maka perlu dilihat asal-usul kata tasawuf tersebut. Menurut bahasa, tasawuf (tashawwuf) berasal dari kata sufi (shûfî), sedangkan kata sufi sendiri ada yang mengatakan berasal dari kata shafấ' (kesucian) dan shafwat (pilihan). Ada pula yang mengatakan berasal dari kata al-shaff atau al-shuffat dan ada pula yang mengemukakan berasal dari kata shîf.

Menurut al-Kalâbâdzî, bila kata sufi itu berasal dari kata shafấ' (kesucian) dan shafwat (pilihan), maka kata ini akan menjadi alshafawiyyat. Jika kata sufi ini berasal dari kata alshaff (barisan) atau al-shuffat (bangku), maka kata ini akan menjadi al-shaffiyyat dan al-shuffiyyat. Boleh jadi, kata al-Kalâbâdzî, adanya huruf waw sebelum huruf $f a^{\prime}$ pada kata shûfiyat merupakan tambahan pada kata shaffiyyat dan kata shuffiyyat, yang berfungsi memperpanjang di dalam pengucapannya, sebagaimana yang biasa berlaku. Akan tetapi, al-Kalâbâdzî tetap mengatakan bahwa dari sudut bahasa yang benar kata sufi itu berasal dari kata shîf sehingga pengucapannya seperti halnya kata itu sendiri. ${ }^{19}$

Akan tetapi, tidak semua orang mengatakan bahwa asal-usul kata sufi itu dari shûf, yakni shôf dalam arti tashawwafa (memakai baju wol), sebagaimana kata taqammasha (dari kata qamîsh) yang berarti memakai baju gamis. “Orang Arab,"

\footnotetext{
${ }^{17}$ Al-Hujwîrî, Kasyf al-Mahjûub, 237-38.

${ }^{18}$ Al-Hujwîrî, Kasyf al-Mahijûb, 227.

${ }^{19} \mathrm{Abû}$ Bakr Muhammad al-Kalâbâdzî, al-Ta'arruf, 33.
}

kata Qusyayrî(w. 465 H/1073 M), "tidak mengkhususkan makna tashawwafa dengan pengenaan pakaian wol, tapi ada yang mengaitkan kata sufi itu dengan sifat masjid Rasulullah Saw, ada yang menghubungkan dengan kata al-shafwu (suci), dan ada yang menisbahkan kepada kata al-shaff (barisan)." Namun, dalam pandangan Qusyayrî, penisbatan kepada sifat masjid Nabi Saw. bukan untuk para sufi; kata al-shafwu sebagai asal kata sufi sangat jauh dari segi tata bahasa Arab; dan kata al-shaff tidak sesuai dengan penisbatan kepada kata sufi. Tampaknya, dari beberapa pendapat ini Qusyayrî ingin mengatakan bahwa asal kata sufi yang benar adalah dari kata shîf, yang menurutnya bukan merupakan kata jadian (ghayru musytaq), melainkan kata yang baku (jâmid), sebagaimana nama julukan (gelar). ${ }^{20}$

Di samping itu, ada pula yang berpendapat bahwa kata sufi itu berasal dari kata sophos (hikmat) dalam bahasa Yunani. Namun, pendapat ini ditolak walau diakui bahwa kaum sufi itu memang berkaitan erat dengan hikmat. Alasannya adalah dikarenakan huruf sigma dalam bahasa Yunani ketika diterjemahkan ke dalam bahasa Arab menjadi huruf sin, bukan shad, seperti kata philosophia menjadi falsafat. Oleh karena itu, kalau kata sufi itu berasal dari kata sophos seharusnya menjadi sûfì, bukan shûfi. ${ }^{21}$

Walaupun kata sufi itu dari segi bahasa yang benar berasal dari kata shûf dan sufi itu disebut sufi dikarenakan pakaian mereka dari shûf (wol), tetapi munculnya beberapa teori tentang asal-usul kata sufi itu tampaknya menunjukkan indikasi bahwa para sufi itu memang memiliki kualitaskualitas tersebut. Mereka memang mempunyai sifat-sifat seperti ahl al-shuffat (miskin, tapi rajin beribadah dan baik hati/dermawan), mereka memang berada di shaff terdepan, dan mereka memang orang-orang yang disucikan Allah Swt. Di sinilah al-Hujwîrî mengatakan bahwa secara umum kesucian (shafấ) itu terpuji dan ketidaksucian (kotor, kadr) itu tercela. "Oleh karena itu," tulis al-Hujwîrî, "para pendukung

\footnotetext{
${ }^{20} \mathrm{Abul}$ Qasim Abdul Karim Hawazin al-Qusyairî an-Naisaburi, Risalah Qusyairiyah: Sumber Kajian Ilmu Tasawuf (Jakarta: Pustaka Amani, 2002), 415.

${ }^{21}$ Muhammad Ghallâb, al-Tashawwuf al-Muqâran (Kairo: Maktabat Nahdhat Mishra wa Muthbi'utihâ, t.t.), 27 dan Titus Burckhardt, An Introduction to Sufi Doctrine (Kashmir-Lahore: SH. Muhammad Asyraf, 1973), 3.
} 
keyakinan ini telah menyucikan akhlak dan tindakan mereka serta berusaha membebaskan diri mereka dari noda-noda bawaan." Disebabkan kesucian (baik) akhlak dan tindakan mereka serta kesucian batin (jiwa) mereka itulah mereka disebut sufi." 22 Jadi, inti sufisme atau tasawuf adalah penyucian diri sehingga sufi itu disebut sufi dikarenakan kesucian batin mereka atau kesucian hati mereka, dan kesucian mereka ini hanya untuk Allah Swt. semata. ${ }^{23}$

Dengan kata lain, sufi adalah orang yang telah suci batinnya atau kalbunya dan telah "sampai" kepada alberusaha untuk mencapai kesucian ini disebut mutashawwif disebabkan tashawwuf termasuk ke dalam bentuk tafâ'ul, yang mengandung makna "bersusah payah" (takalluf). Dengan demikian, tasawuf adalah sebuah upaya penyucian diri untuk mendekatkan diri kepada Allah Swt. ${ }^{24}$

Adapun munculnya teori-teori yang berbeda tentang sejarah kemunculan tasawuf dan tentang asal-usul kata tasawuf itu disebabkan teori-teori itu muncul jauh belakangan dibandingkan keberadaan tasawuf itu sendiri. Abû al-Hasan 'Alî b. Ahmad b. Sahl al-Bûsyinjî (w. 348 H), seperti telah dikutip di atas, menyatakan, "Tasawuf pada saat ini merupakan nama tanpa hakikat, tetapi sebelumnya merupakan hakikat tanpa nama" 25

Dari ungkapan al-Bûsyinjî itu dapat diketahui bahwa tasawuf sebelumnya, yakni pada masa sahabat, tâbi'în dan tâbi'u at-tâbi'în, merupakan hakikat (amaliah) tanpa nama, tapi pada masanya (abad keempat hijriah) merupakan nama tanpa hakikat. Hal ini berarti, perilaku sufistik telah ada sebelum istilah tasawuf itu sendiri ada sehingga ketika istilah itu ada memunculkan beberapa teori yang berbeda. Pendapat al-Bûsyinjî ini, tentu saja, bertentangan dengan pendapat Abû Nashr al-Sarrâj al-Thûsî yang menyatakan bahwa istilah sufi telah ada sebelum datangnya Islam. ${ }^{26}$

Namun, dua pandangan itu dapat disatukan dengan menyatakan bahwa teori-teori tentang

${ }^{22}$ Al-Hujwîrî, Kasyf al-Mahjûu, 227.

${ }^{23}$ Al-Hujwîrî, Kasyf al-Mah jûb, 228.

${ }^{24}$ Al-Hujwîrî, Kasyf al-Mahjûub, 231 dan Abu al-Qasim alQusyairi, Sufi Book of Spiritual Ascent (al-Risalah al-Qusyairiyah), terj. Rabia Harris (Chicago: ABC International Group Inc., 1997), 297.

${ }^{25}$ Al-Hujwîrî, Kasyf al-Mahiûb, 239.

${ }^{26} \mathrm{Abû}$ Nashr al-Sarrâj, al-Luma', 42-3. asal-usul tasawuf itu berbeda-beda dikarenakan penulis-penulis mengenai asal-usul tasawuf itu lahir jauh belakangan. Jadi, yang lahirnya jauh belakangan adalah penulis-penulis tentang asalusul kata sufi atau tasawuf, bukan waktu dikenalnya istilah tasawuf. Al-Sarrâj sendiri, yang bukunya dianggap sebagai buku pertama mengenai pedoman tasawuf yang tetap eksis hingga sekarang, hidup di pertengahan abad keempat hijriah (w. 377 H/988 M). Padahal, sebagaimana akan diungkap di bawah tatkala mengungkap sejarah tasawuf, kata sufi atau tasawuf sebagai istilah telah ada sebelum Islam dan dipergunakan secara luas pada abad kedua hijriah atau pada paruh kedua abad kedelapan masehi. Artinya, terdapat sekitar dua abad antara meluasnya penggunaan kata sufi atau tasawuf itu dengan hidupnya al-Sarrâj. Begitu juga jaraknya dengan kehidupan Abû Bakr Muhammad al-Kalâbâdzî (w. 385 H/995 M) dan Abû Thâlib al-Makkî (w. 386 H/996 M), dua tokoh penulis buku pedoman tasawuf yang hidup sezaman dengan al-Sarrâj. Dengan demikian, tidak aneh kalau muncul beberapa teori tentang asal-usul kata tasawuf.

Selain itu, perbedaan teori-teori itu mungkin juga disebabkan sang perumus teori merumuskan teorinya berdasarkan informasi dan penglihatannya terhadap keadaan atau sifat-sifat sang sufi, yang boleh jadi informasi dan penglihatan mereka pun tidak sama. Akibatnya, muncullah teori-teori yang berbeda tentang kemunculan dan asal-usul tasawuf, meski perbedaan itu dari segi kualitas menunjukkan kebenarannya. Artinya, kaum sufi memiliki kualitas sebagaimana yang diindikasikan dari teori-teori tersebut: mereka memakai wol (shûf), mereka berada di barisan terdepan (al-shaff alawwal), mereka miskin, tapi rajin ibadah dan baik hati seperti ahl al-shuffat, mereka orang-orang suci (shafấ) dan pilihan (shafwat), dan merekapun orang-orang bijak (sophos).

\section{Sejarah Tasawuf}

Tokoh yang pada awalnya sebutan sufi ditujukan kepadanya adalah Abû Hâsyim al-Kûfî (w. 160/776) ${ }^{27}$ atau, ada juga yang menyebutnya

27 'Alî ibn 'Utsmân al-Hujwîrî, Kasyf al-Mah jûub, 231 dan Abu al-Qasim al-Qusyairi, Sufi Book of Spiritual Ascent (al-Risalah alQusyairiyah), 297. 
dengan nama, 'Utsmân bin Syârik dari Kûfah. Namun, Abû Hâsyim bukanlah sufi yang pertama dikarenakan tasawuf pada mulanya berbentuk gerakan kezuhudan (asketis). "Tipe yang tertua dari sufisme (tasawuf)," tulis Reynold A. Nicholson, "adalah kehidupan asketis." 28 Nicholson juga mengatakan bahwa istilah sufi itu pertama kalinya dikenakan pada orang-orang Islam yang hidup asketis. ${ }^{29}$ Dengan kata lain, sufisufi yang awal itu sebelum disebut sufi disebut zahid-zahid (zuhhâd), ${ }^{30}$ meski ada pula yang menyebut zahid-zahid itu sebagai tokoh-tokoh sufi yang awal. ${ }^{31}$ Dengan demikian, gerakan tasawuf pada mulanya adalah gerakan kezuhudan dan sebutan sufi itu pada awalnya ditujukan kepada zahid-zahid tersebut. ${ }^{32}$

Zahid-zahid itu disebut sufi disebabkan mereka memakai pakaian wol dari bulu domba (shûf). Menurut Nicholson, gaya ini meniru gaya hidup asketik kaum Nasrani ${ }^{33}$ atau, menurut Julian Baldick, gaya ini terpengaruh oleh gaya hidup asketik kaum Nasrani. ${ }^{34}$

Pengaruh asketik Nasrani terhadap tasawuf atau zahid-zahid itu mungkin saja benar, tetapi mungkin juga salah (dalam arti, tidak ada pengaruh dari Nasrani atau agama-agama dan tradisi-tradisi lain terhadap tasawuf). Pengaruh asketik Nasrani terhadap tasawuf dikatakan "mungkin saja benar" disebabkan terbukti ada beberapa sufi (zahid), seperti A $\underline{h m a d}$ ibn al-

\footnotetext{
${ }^{28}$ Reynold A. Nicholson, The Mystics of Islam, 4 dan A.J. Arberry, Sufism, 35.

${ }^{29}$ Reynold A. Nicholson, The Mystics of Islam, 3-4.

30 Seyyed Hossein Nasr, Living Sufism (London: Unwin Paperbacks, 1980), 99.

${ }^{31}$ A.J. Arberry, Sufism, 33.

${ }^{32}$ Perbedaan gerakan kezuhudan dan gerakan tasawuf adalah gerakan kezuhudan merupakan gerakan murni keagamaan (kesalihan, spiritualitas), sementara gerakan tasawuf merupakan gerakan keagamaan (spiritualitas) yang telah dimasuki unsurunsur intelektualitas, gerakan tasawuf merupakan elaborasi terhadap gerakan kezuhudan, gerakan kezuhudan tidak mengandung unsur teosofi, sedangkan gerakan tasawuf telah mengandung unsur teosofi, gerakan kezuhudan merupakan gerakan hidup sederhana dan menjauhi kenikmatan duniawi, sementara gerakan tasawuf merupakan gerakan yang menjadikan kehidupan zuhud itu sebagai langkah awal untuk menggapai kehidupan spiritual yang lebih tinggi. Lih. M. Hamiduddin, "Early Sufis: Doctrine," dalam M.M. Syarif (Ed.), A History of Muslim Philosophy (Delhi: Low Price Publications, 1995), 316; A.J. Arberry, Sufism, 33; dan Reynold A. Nicholson, The Mystics of Islam, 6.

${ }^{33}$ Reynold A. Nicholson, The Mystics of Islam, 4.

${ }^{34}$ Julian Baldick, Mystical Islam: An Introduction to Sufism (London: I.B. Tauris \& Co Ltd., 1989), 15.
}

Anwârî̀ dan Ibrâhîm ibn Adham, yang melakukan dialog atau belajar dengan pendeta Nasrani. ${ }^{35}$ Di lain hal, semisal dikatakan Arberry, sudah lazim disepakati bahwa tidak satupun gerakan keagamaan lahir dan berkembang tanpa berbenturan dengan berbagai keyakinan dan kepercayaan lain yang telah mapan, yang cenderung meninggalkan pengaruh dalam pembentukan pemikiran dan perasaan baru. ${ }^{36}$

Walau begitu, landasan-landasan tasawuf beserta amalan-amalan tasawuf telah terpancang kukuh, jauh sebelum ia membuka kemungkinan bagi pengaruh-pengaruh dari luar. "Ketika pengaruh itu akhirnya terasa," tulis Martin Lings, "maka pengaruh-pengaruh itu hanya menyentuh permukaannya saja." ${ }^{37}$ Begitu pula Nicholson, sebagaimana dikutif Taftâzânî, menyatakan, "meski kami mengakui agama Nasrani mempunyai dampak terhadap pembentukan tasawuf dari jenis pertamanya, tetapi kami berpendapat bahwa ucapan-ucapan para sufi yang asketis, seperti Ibrâhîm ibn Adham, Fudhail ibn 'Iyâdh dan Syaqiq al-Balakhî, tidak menunjukkan bahwa mereka itu terkena dampak agama Nasrani, kecuali sedikit sekali. Dalam kata lain, tampaklah bahwa tasawuf jenis asketis ini adalah hasil gerakan Islam itu sendiri, bahkan hasil nyata dari ide Islam tentang Allah." ${ }^{38}$ Dalam kalimat Harun Nasution, terlepas dari kemungkinan adanya atau tidak adanya pengaruh dari luar, ayat-ayat dan hadis-hadis Nabi Saw. dapat membawa kepada timbulnya aliran sufi dalam Islam, yaitu kalau yang dimaksud dengan sufisme ialah ajaran-ajaran tentang berada sedekat mungkin dengan Tuhan. ${ }^{39}$

Dari pernyataan Martin Lings dan

${ }^{35}$ Reynold A. Nicholson, The Mystics of Islam, 11 dan A.J. Arberry, Sufism, 36-7.

${ }^{36}$ A.J. Arberry, Sufism, 11.

${ }^{37}$ Martin Lings, What is Sufism? (London: George Allen \& Unwin Ltd., 1975), 5. Dengan demikian, tidak tepat tuduhan Ahmad bin Abdul Aziz al-Hushain dan Abdullah Mustofa Numsuk bahwa tasawuf itu merupakan ajaran Budha. Kalaupun ternyata pengaruh itu ada, maka pengaruh itu hanya menyentuh permukaannya saja sehingga tidak mampu merubah esensinya. Oleh karena tidak mampu merubah esensinya, maka tidak dapat dikatakan bahwa tasawuf itu merupakan ajaran Budha.

${ }^{38} \mathrm{Abu}$ al-Wafa' al-Ghunaimi al-Taftazani, Sufi dari Zaman ke Zaman, terj. Ahmad Rofi' 'Utsmani (Bandung: Pustaka, 1985), 56.

${ }^{39}$ Harun Nasution, Falsafat $\mathcal{E}$ Mistisisme dalam Islam (Jakarta: Bulan Bintang, 1995), Cet. Ke-9, 61. 
Nicholson itu dapat ditegaskan bahwa pengaruh Nasrani dan agama-agama atau tradisi-tradisi lain, bila pengaruh itu ada, maka hanya menyentuh permukaannya saja atau hanya sedikit saja. Inti ajaran tasawuf tidak tersentuh sama sekali. Bahkan, dapat dikatakan, kalau ada pengaruh agama Nasrani, agama-agama dan tradisi-tradisi lain, termasuk ajaran Buddha, maka pengaruh itu terjadi ketika gerakan kezuhudan telah berubah menjadi gerakan tasawuf. Sufi-sufi awal (zahid-zahid) tidak terpengaruh oleh ajaran-ajaran non-Islam, sehingga inti ajaran tasawuf tetap tidak berubah, tetap Islam.

Zahid-zahid (sufi-sufi awal) itu tidak terpengaruh oleh asketisme Nasrani dikarenakan: Pertama, kesamaan pakaian, yakni memakai wol (shîf), tidak dapat dijadikan alasan bahwa zahidzahid itu terpengaruh oleh asketik-asketik Nasrani disebabkan memakai pakaian wol dalam tradisi Islam dipandang bukan monopoli Nabi Isa a.s. yang kemudian diikuti asketik-asketik Nasrani, tetapi nabi-nabi lain pun, termasuk Nabi Muhammad Saw., memakai wol. "Namun, wol itu merupakan pakaian para nabi dan rasul." Demikian jawaban Nabi Saw. terhadap keluhan 'Uyainah ibn Hishn yang memusingkan bau pakaian wol ahl al-shuffat. ${ }^{40}$

Selain itu, sahabat Abû Mûsâ al-Asy'arî meriwayatkan pula bahwa Nabi Saw. bersabda: "Sesungguhnya sebanyak 70 orang nabi telah melewati padang al-Ruh $\hat{a}^{\prime}$ dengan kaki telanjang (tanpa sandal, alas kaki) dan mengenakan mantel, dan mereka sedang memperbaiki al-bait al-'atîq." Abû Mûsâ al-Asy'arî pun meriwayatkan: "Nabi Saw. berpakaian wol, mengendarai keledai dan mendatangi orang-orang lemah yang meminta bantuan." 41

Kedua, Nabi Saw. memakai wol, maka para sahabat pun, terutama sahabat yang dikenal sebagai ahl badr dan atau ahl al-shuffat, ${ }^{42}$ berpakaian wol. Hâsan al-Bashrî menyatakan bahwa dia telah bertemu dengan 70 orang yang mengikuti perang Badar dan pakaian mereka adalah wol. ${ }^{43}$ Berpakaian wol, hidup mulia dan

\footnotetext{
${ }^{40}$ Abû Bakr Muhammad al-Kalâbâdzî, al-Ta'arruf, 30.

${ }^{41} \mathrm{Abû}$ Bakr Muhhammad al-Kalâbâdzî, al-Ta'arruf, 31.

${ }^{42}$ Tentang nama-nama ahl al-shuffat ini lihat Al-Hujwîrî, Kasyf al-Mah jûub, Bab 9.

${ }^{43}$ Abû Bakr Muhammad al-Kalâbâdzî, al-Ta'arruf, 31.
}

berzuhud ini dilakukan para sahabat, seperti dikemukakan Arberry, atas dasar meneladani Nabi Saw. ${ }^{44}$ Apa yang dilakukan sahabat-sahabat ini ditiru generasi sesudahnya (tâbi'în) dan generasi sesudah sahabat ditiru generasi setelahnya lagi (tâbi' al-tâbi'în) dan seterusnya. Dengan kata lain, yang pertama (Nabi Saw.) menyeru kepada yang kedua (sahabat), yang kedua menyeru kepada yang ketiga (tâbi'în), yang ketiga menyeru kepada yang keempat (tâbi' altâbi $\left.{ }^{\prime} \hat{n}\right)$, dan seterusnya. ${ }^{45}$ Dengan demikian, kehidupan zuhud dan berpakaian wol bersumber langsung dari Nabi Saw., bukan dari asketikasketik Nasrani. "Tidak ada alasan yang memadai untuk meragukan keotentikan sejarah spiritual yang diwariskan para guru sufi," tulis Titus Burckhardt, "dikarenakan warisan para guru sufi ini dapat ditelusuri dalam suatu mata rantai (silsilat) yang tidak terputus sampai Nabi Saw. sendiri." ${ }^{46} \mathrm{Hal}$ ini berarti, ajaran para guru sufi berasal dari Nabi Saw., bukan dari sumbersumber di luar Islam, sehingga - seperti dikatakan Burckhardt-tidak ada alasan yang memadai untuk meragukan keotentikan sejarah spiritual yang diwariskan para guru sufi.

Salah satu bukti bahwa generasi tâbi'în meniru generasi sahabat adalah Hâsan al-Bashrî (w. $110 \mathrm{H} / 728 \mathrm{M}$ ), tokoh terpenting gerakan zuhud, adalah murid 'Alî ibn Abî Thâlib (dan Hâsan ibn 'Alî). Uwais al-Qurni juga murid 'Alî,, ${ }^{47}$ sehingga ada hubungan yang tidak terputus antara sahabat dengan generasi tâbi în.

Ketiga, hidup zuhud dan berpakaian wol itu berasal dari Nabi Saw., yang berarti dapat dipahami bahwa tasawuf itu bersumber langsung dari al-Qur'an dan Hadis Nabi Saw. "Al-Qur'an merupakan pewenang tertinggi," tulis Arberry, "yang darinya para sufi mencari tuntunan dan pembenaran." Arberry pun mengakui bahwa alHadis merupakan "pilar kedua" setelah alQur'an, yang kepadanya sang sufi dan seluruh generasi Muslim menyandarkan kepercayaan dan kehidupannya. "Pilar ketiga" adalah ajaran waliwali-Nya dan "pilar keempat" adalah

${ }^{44}$ A.J. Arberry, Sufism, 32.

${ }^{45}$ Mengenai estafetisasi ajaran Nabi Saw. ini lihat Al-Hujwîrî, Kasyf al-Mahjûb, 7-13.

${ }^{46}$ Titus Burckhardt, An Introduction to Sufi Doctrine, 5.

${ }^{47}$ S.H. Nasr, Living Sufism, 99.

${ }^{48}$ A.J. Arberry, Sufism, Bab Introduction. 
pengalaman-pengalaman spiritual pribadi sang sufi. ${ }^{48} \mathrm{Jadi}$, tasawuf tidak bersumber dari 'sesuatu' di luar Islam, tetapi secara otentik bersumber dari Islam sendiri, bersumber dari al-Qur'an dan Hadis, di samping ajaran para wali dan pengalaman spiritual pribadi para sufi. "Sufi juga termasuk kelompok ahli ilmu," tulis al-Sarrâj, "yang mengamalkan ayat al-Qur'an dan Hadishadis Rasulullah Saw." 49 Burckhardt pun menegaskan bahwa alasan yang paling menentukan untuk menyetujui kalau asal usul sufisme pengikut Muhammad Saw. adalah terletak pada sufisme itu sendiri. Lebih lanjut Burckhardt mengemukakan, sekiranya kearifan sufi itu berasal dari sumber di luar Islam, maka orang-orang yang mencita-citakan kearifan ituyang sudah tentu tidak berpegang kepada teksteks buku dan tidak pula semata-mata bersifat mental-spiritual-tidak dapat menyandarkan kepada simbolisme al-Qur'an dan tidak akan mampu menyadari bahwa kearifan itu selalu kembali lagi serta tidak akan sanggup memahami kalau, dalam kenyataannya, segala sesuatu yang membentuk suatu bagian integral dari metode spiritual sufisme adalah secara terus-menerus diambil dari al-Qur'an dan ajaran Nabi Saw. ${ }^{50}$ Pandangan Arberry, Burckhardt dan al-Sarrâj ini menunjukan tidak mungkinnya ajaran tasawuf dari sumber non-Islam, yang berarti pula tidak mungkinnya membuktikan ketidakotentikan tasawuf.

Keempat, kata tasawuf atau sufi bukanlah kata yang baru, ${ }^{51}$ sehingga ajaran tasawuf bukanlah ajaran yang baru yang berasal dari ajaran nonIslam, tetapi benar-benar merupakan bagian dari ajaran Islam. Menurut al-Sarrâj, kata itu telah dipergunakan para era tâbi'în, tâbi' al-tâbi'în, pada era Nabi Saw. dan sahabat, bahkan pada era praIslam. ${ }^{52} \mathrm{Al}-$ Sarrâj mengutip laporan $\underline{\text { Hasan Bashrî }}$ yang menginformasikan bahwa dia melihat seorang sufi sedang berthawaf (mengelilingi $K a$ 'bah) dan dia menawarinya sesuatu, tetapi sufi itu tidak mau menerimanya. Sang sufi itu pun

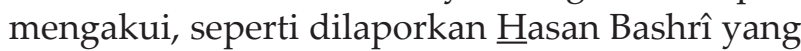

\footnotetext{
${ }^{49}$ Abû Nashr al-Sarrâj, al-Luma', 31.

${ }^{50}$ Titus Burckhardt, An Introduction to Sufi Doctrine, 5-6.

${ }^{51}$ Al-Qusyairî menyatakan secara eksplisit, sebagaimana dinukil Hamiduddin, bahwa kata tasawuf telah digunakan umat sebelum abad ke-2 H/8 M atau sebelum tahun $200 \mathrm{H} / 815 \mathrm{M}$. M. Hamiduddin, "Early Sufis," 315-16.

${ }^{52}$ Abû Nashr al-Sarrâj, al-Luma', 42-3.
}

dinukil al-Sarrâj, bahwa dia masih memiliki uang empat dawânîq (2/3 dirham). "Cukuplah bagiku," kata sufi itu sebagaimana informasi Hasan Bashrî yang ditulis al-Sarrâj, "apa yang aku miliki ini." 53 Bagi al-Sarrâj, laporan Hasan Bashrî ini merupakan bukti bahwa kata itu telah dipergunakan pada masa Hasan Bashrî, masa tâbi în. ${ }^{54}$ Kemudian, al-Sarrâj merujuk ungkapan Sufyan al-Tsauri (w. 161/777) ${ }^{55}$ yang mengatakan, "kalau Abû Hasyim itu bukan seorang sufi, niscaya aku tidak akan mengenal makna yang sebenarnya mengenai rahasia pamer (riyấ),"sebagai bukti bahwa kata itu telah digunakan pada zaman tâbi' al-tâbi'în, masa Sufyan al-Tsauri dan Abû Hasyimal-Kûfî (w. 160/ 776).

Selanjutnya, al-Sarrâj mengemukakan bahwa para sahabat itu tidak disebut sufi, meski pada era sahabat ini telah digunakan, dikarenakan bagi sahabat, bersahabat dengan Rasulullah Saw. merupakan suatu kehormatan dan keistimewaan tersendiri, (yang tidak dialami dan dimiliki oleh generasi-generasi sesudah mereka) sehingga untuk menghormati dan memulyakannya mereka disebut sahabat Nabi Saw., bukan sebutan yang lain, termasuk sebutan sufi. Dengan demikian, sebutan sahabat bagi mereka merupakan kemuliaan dan kehormatan atas persahabatannya bersama Rasulullah Saw. Oleh karenanya, ketika para sahabat itu dinisbatkan kepada Rasulullah Saw. yang merupakan keadaan yang paling mulia, maka mustahil mengutamakan mereka dengan suatu keutamaan selain persahabatannya bersama Rasulullah Saw. ${ }^{56}$ Adapun bukti bahwa pada zaman sahabat dan Nabi Saw. kata sufi itu telah digunakan dapat dilihat dari sabda-sabda Nabi

\footnotetext{
${ }^{53}$ Abû Nashr al-Sarrâj al-Thûsî, al-Luma', 42.

${ }^{54}$ Abû Nashr al-Sarrâj, al-Luma', 42-3.

${ }^{55}$ Sufyan al-Tsauri, menurut al-Hujwîrî, merupakan salah satu dari empat tokoh, yakni Abû Hanîfah, Mis'ar ibn Kidam, Syuraik dan Sufyan sendiri, yang diundang Khalifah al-Manshûr untuk dipilih, salah satunya, menjadi qadhi. Di tengah perjalanan menuju Khalifah, Abû Hanîfah usul supaya Mis'ar pura-pura gila, Sufyan supaya lari, dia akan menolak jabatan itu, dan hendaknya Syuraik yang menjadi qadhi. Akhirnya, Syuraik dipilih sebagai qadhi. Al-Hujwîrî, Kasyf al-Mah jûub, 303.

${ }_{56}$ Posisi mereka sebagai sahabat Rasulullah Saw. ini yang membuat mereka menjadi pemimpin-pemimpin ahli zuhud, ahli ibadah, orang-orang yang bertawakal, orang-orang fakir, orangorang yang ridha, orang-orang yang sabar, orang-orang yang
} rendah hati (mukhbitîn) dan lain sebagainya. 
Saw. dan pernyataan-pernyataan Abû Mûsâ alAsy'arî yang telah dinukil di atas.

Terakhir, untuk menunjukkan bahwa kata sufi itu telah dipakai di zaman pra-Islam, al-Sarrâj mengutip kitab "Sejarah Mekkah" (Akhbar Makkah) karya Muhammad bin Ishaq bin Yasar (w. 150/767). Di dalam kitab Akhbar Makkah yang dinukil al-Sarrâj ini diceritakan bahwa sebelum Islam datang pernah terjadi di suatu waktu yang cukup lama tidak seorangpun yang berthawaf di Bayt al- Harâm. Kemudian, datanglah dari negeri yang jauh seorang laki-laki sufi yang berthawaf di Bayt al-Harâm. "Bila cerita ini benar," kata alSarrâj, "maka cerita ini menunjukkan bahwa istilah sufi telah dikenal sebelum masa Islam." Dalam penilaian al-Sarrâj, orang yang dinamai dengan sebutan sufi pada masa pra-Islam ini pastilah orang yang memiliki keutamaan dan kebaikan." 57

Pandangan al-Sarrâj itu, kata M. Hamiduddin, didukung Abû al-Fârâb ibn alJawzî, Zamakhsyari dan Fîrûzâbâdî. Hamiduddin menginformasikan bahwa Zaki Mubârak dalam kitabnya al-Tashawwuf al-Islâmî fî al-Adab wa alAkhlâq telah mengutip dari kitab Talbîs Iblis Ibn Zawzî yang menyebutkan kalau Muhammad ibn Nâshir telah menceritakan kepada Ibn Zawzî tentang Abû Ishâa Ibrâhîm ibn Sa'îd alTokoh yang disebut terakhir ini mengisahkan bahwa 'Abû Muhammad 'Abd al-Ghânî ibn Sa'îd al-Hâfizh pernah bertanya kepada Walîd ibn Qâsim mengenai sebab-sebab seseorang disebut sufi. Walîd ibn Qâsim diinformasikan memberikan jawaban bahwa pada masa pra-Islam telah ada sekelompok orang yang dikenal sebagai sufi (alshûfiyyat). Orang-orang yang disebut sebagai sufi pada zaman pra-Islam ini digambarkan Walîd ibn Qâsim dengan sifat meninggalkan hal-hal yang duniawi demi Tuhan Yang Maha Kuasa dan menjadikan Ka'bah sebagai tempat tetap dan pengabdian (ibadah) mereka. Kemudian, ditegaskan bahwa orang-orang yang hidup seperti mereka inilah yang dikenal sebagai sufi. ${ }^{58}$

Musthafâ 'Abd al-Râziq mengomentari tentang munculnya istilah sufi atau tasawuf di atas dengan menegaskan bahwa penggunaan istilah sufi dan mutashawwif secara luas baru

${ }^{57} \mathrm{Abû}$ Nashr al-Sarrâj, al-Luma', 42-3.

${ }^{58}$ M. Hamiduddin, "Early Sufis: Doctrine," 315. terjadi pada abad kedua hijriah dan sesudahnya. Menurutnya, sama saja apakah istilah sufi ini digunakan untuk menjelaskan orang yang zuhud yang terjadi pada pertengahan abad kedua hijriah; ataukah merupakan suatu istilah yang telah dikenal di dalam Islam sebelum abad kedua hijriah; dan ataukah merupakan suatu istilah yang termasuk istilah jahiliyyah. ${ }^{59}$

Penegasan 'Abd al-Râziq itu sejalan dengan penyebutan tokoh-tokoh tertentu sebagai sufi pada abad kedua hijriah atau pada paruh kedua abad kedelapan masehi, seperti telah disebutkan di atas, yaitu Jâbir ibn Hayyân (tahun kematiannya tidak diketahui secara pasti), seorang kimiawan dan murid Imâm Ja'far alShâdiq (w. 148/765), dan Abû Hâsyim al-Kûfî alShûfî (w. 160/776). Kemudian, di awal abad ketiga hijriah 'Abdak merupakan tokoh pertama di Baghdad yang disebut sufi. Dengan demikian, bisa saja istilah sufi atau tasawuf itu telah dikenal sebelum abad kedua dan, bahkan, sebelum datangnya Islam, tapi istilah ini menjadi populer atau digunakan secara luas pada abad kedua dan ketiga hijriah. Sejak abad kedua dan ketiga hijriah inilah tokoh-tokoh yang sebelumnya disebut zuhhâd, nussâk, 'ubbâd atau qurrâ' disebut sebagai sufi. ${ }^{60}$ Dalam pandangan Arberry, setelah pertengahan abad ketiga hijriah atau kesembilan masehi gelar sufi menjadi sebutan permanen bagi para pelaku kezuhudan. ${ }^{61}$ Dengan demikian, istilah sufi atau tasawuf bukanlah istilah baru dalam Islam. Sebagai sebuah istilah yang tidak baru dalam Islam, berarti tuduhan ketidakotentikan ajaran tasawuf tidak dapat dibuktikan.

\section{E. Penutup}

\footnotetext{
${ }^{59}$ Louis Massignon \& Musthafâ 'Abd al-Râziq mengatakan bahwa al-Sarrâj mengemukakan pendapat ini untuk membebaskan paham tasawuf dari tuduhan sebagai istilah baru yang tidak dikenal pada zaman sahabat dan tâbi'în. Louis Massignon \& Musthafâ 'Abd al-Râziq, Islam \& Tasawuf, terj. Irwan Raihan \& M. Halabi Hamdy (Yogyakarta: Fajar Pustaka Baru, 2001), 44.

60 'Abd al-Qâdir Ahmad 'Athâ', al-Tashawwuuf al-Islâmiy bayn al-Ashâlat wa 'il-Iqtibâs fî̀ 'Ashr al-Nâblisî (Beirut: Dâr al-Jayl, 1987), 180. Muhammad al-Abduh dan Thariq Abdul Halim tidak menyetujui penisbatan sufi untuk zuhhâd, nussâk, 'ubbâd atau qurrâ' ini dikarenakan dia menyatakan bahwa zuhhâd, nussâk, 'ubbâd atau qurrâ' ini merupakan kelompok umat yang berada pada jalur yang benar, sementara kaum sufi dia pandang sebagai ahli bid'ah.Muhammad al-Abduh dan Thariq Abdul Halim, Koreksi bagi Kaum Sufi, 3.

${ }^{61}$ A.J. Arberry, Sufism: An Account of the Mystics of Islam, 35.
} 
Dari uraian-urian di atas dapat dilihat tidak mungkinnya membuktikan ketidakotentikan ajaran tasawuf. Dengan demikian dapat disimpulkan bahwa tidak benar tasawuf itu tidak otentik Islam. Kesimpulan ini atas dasar bukti yang menunjukkan bahwa tasawuf itu otentik ajaran Islam, otentik bersumber dari al-Qur'an dan al-Hadis, seperti di uraikan di atas. Kalau ada pengaruh dari luar, maka pengaruh itu tidak terjadi ketika tasawuf masih dalam bentuk awalnya, yakni dalam bentuk gerakan kezuhudan, tetapi tatkala tasawuf itu telah menjadi gerakan tasawuf yang mengandung unsur-unsur intelektualitas. Itu pun hanya menyentuh permukaannya saja, hanya menyentuh kulitnya saja, sehingga inti ajaran tasawuf tetap ajaran Islam yang tidak terpengaruh oleh unsur apa pun. Oleh sebab itulah benar apa yang dikatakan Titus Burckhardt: "Sufisme (tasawuf) tidak dapat disebut sebagai sesuatu yang ditambahtambahkan kedalam Islam dikarenakan, kalau demikian (sesuatu yang ditambah-tambahkan ke dalam Islam), maka tasawuf akan menjadi sesuatu yang bersifat pinggiran dalam kaitannya dengan sarana-sarana spiritualitas Islam." Kenyataannya, tasawuf merupakan jantung spiritualitas umat Islam hingga sekarang. Wa Allâhu a'lam.[] 
Abduh, Muhammad al- dan Halim, Thariq Abdul. Koreksi bagi Kaum Sufi, terj. A. Bahauddin dan Muslim Muslih. Jakarta: Kalam Mulia, 1998.

'Athâ', 'Abd al-Qâdir Ahmad. al-Tashawwuf alIslâmiy bayn al-Ashâlat wa 'il-Iqtibâs fì 'Ashr al-Nâblisî. Beirut: Dâr al-Jayl, 1987.

Baldick, Julian. Mystical Islam: An Introduction to Sufism. London: I.B. Tauris \& Co Ltd., 1989.

Basyûnî, Ibrâhîm. Nasy'at al-Tashawwuf al-Islâmî. Kairo: Dâr al-Ma'ârif Bimishra, t.t.

Burckhardt, Titus. An Introduction to Sufi Doctrine. Kashmir-Lahore: SH. Muhammad Asyraf, 1973.

Ghallâb, Muhammad. al-Tashawwuf al-Muqâran. Kairo: Maktabat Nahdhat Mishra wa Muthbi'utihâ, t.t.

Hamiduddin, M., "Early Sufis: Doctrine," dalam M.M. Syarif (Ed.). A History of Muslim Philosophy. Delhi: Low Price Publications, 1995.

Hujwîrî, 'Alî ibn 'Utsmân al-. Kasyf al-Mahjûb, terj. ke dalam Bahasa Arab Is'ad Abd alHâdî Qundail. Kairo: Dar al-Kutub, 1974.

Hushain, Ahmad bin Abdul Aziz al- dan Numsuk, Abdullah Mustofa. Kesesatan Sufi: Tasawuf, Ajaran Budha!. Jakarta: Pustaka as-Sunnah, 2001.

Jaiz, Hartono Ahmad. Aliran dan Paham Sesat di Indonesia. Jakarta: Pustaka Al-Kautsar, 2002.

Johansen, Julian. Sufism and Islamic Reform in Egypt: The Battle for Islamic Tradition. Oxford: Clarendon Press, 1996.

Kalâbâdzî, Abû Bakr Muhammad al-. Al-Ta'arruf li Madzhab Ahl al-Tashawwuf. Kairo: Maktabat al-Kulliyyât al-Azhariyyat, 1969.
Lings, Martin. What is Sufism?. London: George Allen \& Unwin Ltd., 1975.

Massignon, Louis, \& Musthafâ 'Abd al-Râziq. Islam \& Tasawuf, terj. Irwan Raihan \& M. Halabi Hamdy. Yogyakarta: Fajar Pustaka Baru, 2001.

Nasr, Seyyed Hossein. Living Sufism. London: Unwin Paperbacks, 1980.

Nasution, Harun. Falsafat \& Mistisisme dalam Islam. Jakarta: Bulan Bintang, 1995.

Nicholson, Reynold A. Th Mystics of Islam. London: Routledge \& Kegan Paul Ltd., 1966.

Qusyairî, Abul Qasim Abdul Karim Hawazin al. Risalah Qusyairiyah: Sumber Kajian Ilmu Tasawuf. Jakarta: Pustaka Amani, 2002.

- - --Sufi Book of Spiritual Ascent (al-Risalah alQusyairiyah), terj. Rabia Harris. Chicago: ABC International Group Inc., 1997 .

Rahman, Fazlur. Islam. Chicago dan London: University of Chicago Press, 1979.

Sirriyeh, Elizabeth. Sufis and Anti-Sufis: The Defence, Rethinking and Rejection of Sufism in the Modern World. RoutledgeCurzon: Taylor \& Francis Group, 1999.

Taftazani, Abu al-Wafa' al-Ghunaimi al-. Sufi dari Zaman ke Zaman, terj. Ahmad Rofi' ‘Utsmani. Bandung: Pustaka, 1985.

Thûsî, Abû Nashr al-Sarrâj al-. Al-Luma', Pentahqiq dan Kata Pengantar: 'Abd alHalîm Mahmûd dan Thâhâ 'Abd al-Bâqî Surûr. Kairo: Maktabat al-Tsaqâfat alDîniyyat, t.t. 